\title{
Relationship Between Platelet Distribution Width and Papillary Thyroid Cancer
}

\section{Platelet Dağılım Genişliği ile Papiller Troid Kanseri Ilişkisi}

\author{
Özkan Yılmaz* and Remzi Kızıltan \\ School of Medicine, University of V an Yuðuncu Yil Department of General Surgery, Dursun Odabas Medical Center, \\ Van, Turkey
}

\begin{abstract}
Objective: Thyroid nodules are the most common disease of the thyroid gland. The main objective of the present study was to provide an answer to one question: "Is it possible to acquire information about malignancy potential of thyroid nodules using the tests readily available at all centers.

Materials and Methods: The present study retrospectively reviewed preoperative results of hemogram, biochemical parameters and pathology reports of a total 275 patients, who underwent bilateral total thyroidectomy procedure in the Department of General Surgery at our faculty from 2014 to 2015.

Results: The mean age was $47.60 \pm 12.79$ (20-79) years. Of patients, $84.7 \%$ (233) were females and $14.9 \%$ (41\%) were males. Of patients that underwent bilateral thyroidectomy, pathologic examination revealed nodular hyperplasia in 180 patients and papillary thyroid cancer (PTC) in 95 patients. TSH levels before surgery were lower in patients with nodular hyperplasia compared to patients with papillary thyroid cancer and the difference was statistically significant $(\mathrm{p}=0.003)$. There was no statistically significant difference in hematological parameters measured before surgery between the two groups. However, platelet distribution width was significantly higher in female patients with multicentricity compared to those without multicentricity $(\mathrm{p}=0.047)$.

Conclusion: The study suggests that hemogram and biochemical tests that are routinely performed in preoperative workup do not easily differentiate malignant lesions from the benign lesions. However, high platelet distribution width (PDW) may raise the suspicion of malignant lesions with multicentricity.
\end{abstract}

Key Words: Platelet distribution width, papillary thyroid cancer, thyroid, platelet

\section{Introduction}

Early diagnosis is the only chance for cure in most malignancies. For this reason, physicians have made tremendous endeavors for years to find diagnostic methods that would allow early diagnosis of cancer. Is there a diagnostic method for papillary thyroid cancer, which has a far better prognosis compared to most malignancies? The question whether or not it is

\section{ÖZET}

Amaç: Tiroid nodülleri, tiroidin en sık rastlanılan hastalığıdır. Her merkezde rahatlıkla yapılabilinen tetkiklerle nodüllerin malignite potansiyelleri hakkında bilgi edinmek mümkünmüdür sorusu bu çalışmanın temel amacı olmuştur.

Gereç ve Yöntem: Fakültemiz genel cerrahi kliniğinde 2014-2015 yıllarında bilatateral total troidektomi yapılan 275 hastanın preoperatif hemogram ve biyokimyasal parametreleri ve patoloji raporları retrospektif olarak incelenmiştir.

Bulgular: Bilateral total tiroidektomi uygulanan olgulardan 180'inin patoloji sonucu nodüler hiperplazi, 95'inin ise papiller tiroid kanseriydi(PTC). Patoloji sonucu nodüler hiperplazi olan olguların cerrahi öncesi bakılan TSH düzeyleri patoloji sonucu papiller kanser gelenlere göre daha düşüktü $\mathrm{Bu}$ sonuç istatiksel olarak anlamlı bulundu ( $\mathrm{p}=0.003)$. İki grup arasında cerrahi öncesi bakılan hematolojik parametreler açısından istatistiksel anlamda fark yoktu. Ancak kadın olgularda multisentrisite olanlarda olmayanlara göre platelet dağılım genişliği istatiksel olarak daha yüksekti $(\mathrm{p}=0.047)$.

Sonuç: Çalışmanın sonucu göstermiştir ki, preop hazırlıkta rutin yapılan hemogram ve biyokimyasal tetkilerle malign benign ayrımı kolay değildir. Ancak yüksek platelet dağılım genişliği (PDW) ile malign karekterli kitlelerde multisentrisiteden şüphelenmek mümkündür.

Anahtar Kelimeler: Papiller troid kanser, platelet dağılım genişliği, troid, platelet

possible to differentiate malignant from benign nodules and acquire information about features of thyroid nodules using the tests readily available at all centers has been the main focus of the present study.

Thyroid nodules are the most common disease of the thyroid gland. The finding of thyroid nodules in more than $50 \%$ of cases in autopsy series and finding of small nodules using ultrasonography in thyroid glands

${ }^{*}$ Corresponding author: Özkan Yilmaz MD. School of Medicine, University of Van Yuzuncu Yil Department of General Surgery, Dursun Odabaş Medical Center, Van, Turkey 65090, Phone: +90 43221504 70, Fax:+90 43221683 52, E-mail: drozyilmaz@gmail.com

Geliş Tarihi: 09.01.2017, Kabul Tarihi: 05.04.2017 
that are found to be normal on palpation suggests the importance and extensiveness of nodular goiter (a). Either malignant or benign, the prevalence of such lesions in general population ranges from 4 to $7 \%$, and 5 to $14 \%$ of these lesions has malignant character (1). Thyroid malignancies are the most commonly encountered endocrine malignancy and they account for $1 \%$ of all malignancies and $0.2 \%$ of cancer-related mortality (2). The incidence of thyroid cancer has increased rapidly in the last few decades. There has been also an increase in the incidence of PTC, whereas no change has been noted in the incidence of other thyroid cancers (3). In general, thyroid malignancies more commonly occur in females and papillary thyroid cancer accounts for $85-92.7 \%$ of thyroid cancers occurring in females (4).

Most patients with a malignancy are prone to hypercoagulobility state. In these patients, platelets release angiogenic growth factors and predispose to thrombosis by adhering tumor capillaries. As a result, venous thromboembolism associated with platelet activation occurs 4 to 6 -fold more commonly, when compared to healthy individuals (5). The factors stimulating platelet production also cause an increase in platelet distribution width. PDW indicates changes in the size of platelets and it may point to active platelet release (6).

\section{Materials and methods}

The study was performed retrospectively. 275 patients who was underwent bilateral total thyroidectomy in the last 2 years were included the study. Patients' age, sex, pre-op TSH, fT4, fT3 and $\mathrm{CBC}$ levels were recorded to prepare forms.

The subjects were grouped according to the pathology as multinodular goiter cases and papillary thyroid cancer cases. Also papillary cancer cases were grouped according to sex, tumor diameter, tumor characteristics and histological variant.

Patients with a history of heamatological disorders, renal failure, nutritional anemia or iron deficiency were excluded from the study. None of the subjects were receiving iron, B12 or folic acid. Also patients who had lobectomy and pathology of the patients with medullary thyroid cancer, follicular cancer or anaplastic cancer were excluded from the study.

Fasting venous blood samples were drawn in the morning after an 8-hr fast. All of the CBC analyses were performed in the hematology laboratory of our hospital. An automatic blood counter (BeckmanCoulter, LH 780, USA) was used for whole blood counts. Hormonal tests (TSH, fT4, fT3) were performed according to the microparticle chemiluminescence method using an Architect i2000SR device.

The study results were transferred from forms to SPSS 16 computer statistical analysis software and statistical analyses were performed. Paired t-test was used for comparison of the groups. Results were expressed as mean \pm standard deviation and a $p$ value of $<0.05$ was considered statistically significant.

\section{Results}

The mean age of the study patients was $47.60 \pm$ 12.79 (20-79) years. Of these patients, 84.7\% (233) were females and $14.9 \%$ (41) were males. Of patients that underwent bilateral thyroidectomy, pathologic examination revealed nodular hyperplasia in 180 patients and papillary thyroid cancer (PTC) in 95 patients

Preoperative hematologic and hormonal parameters obtained in patients that were diagnosed with nodular hyperplasia or papillary thyroid carcinoma after bilateral total thyroidectomy are presented in Table 1. TSH levels before surgery were lower in patients with nodular hyperplasia compared to patients with papillary thyroid cancer. The difference was statistically significant $(\mathrm{p}=0.003)$. At the same time, weight of the thyroid gland was higher in patients with nodular hyperplasia compared to patients with papillary thyroid cancer $(\mathrm{p}<0.001)$. There was no statistically significant difference in hematological parameters evaluated in the preoperative period between the two groups (Table 1).

Of 95 patients with papillary thyroid cancer, 79 $(83.2 \%)$ were females and $16(16.8 \%)$ were males. Among these patients, the largest diameter of the cancer focus was below $1 \mathrm{~cm}$ in 45 patients. Tumor characteristics and histological subvariants are presented in Table 2 and 3 (Table 2, Table 3).

Of patients with papillary cancer, 79 were females. Of these patients, 29 had multicentricity. Comparative statistics of hematological and hormonal parameters according to the presence of multicentricity in females with papillary cancer are provided in Table 4. Platelet distribution width was significantly higher in cases with multicentricity $(p=0.047)$ (Table 4).

\section{Discussion}

Early diagnosis is the only chance for cure in most malignancies. For this reason, physicians have made tremendous endeavors for years to find diagnostic 
Table 1. The table shows comparative assessment of hematological and hormonal parameters obtained before surgery in patients who were diagnosed with nodular hyperplasia or papillary thyroid cancer after bilateral total thyroidectomy

\begin{tabular}{|c|c|c|c|c|c|}
\hline & & $\mathrm{n}$ & Mean & $\mathrm{SD}$ & $\mathrm{p}$ \\
\hline \multirow[t]{2}{*}{ Age } & Nodular hyperplasi & 180 & 48,49 & 12,63 & \multirow{2}{*}{0,114} \\
\hline & Papillary carcinoma & 95 & 45,93 & 13,01 & \\
\hline \multirow[t]{2}{*}{ Thyroid stimulating hormone (TSH) } & Nodular hyperplasia & 180 & 0,89 & 1,29 & \multirow{2}{*}{0,003} \\
\hline & Papillary carcinoma & 95 & 1,37 & 1,11 & \\
\hline \multirow[t]{2}{*}{ Free thyroxine (fT4) } & Nodular hyperplasia & 180 & 1,02 & 0,20 & \multirow{2}{*}{0,692} \\
\hline & Papillary carcinoma & 94 & 1,03 & 0,22 & \\
\hline \multirow[t]{2}{*}{ Free triiodothyronine (fT3) } & Nodular hyperplasia & 100 & 3,32 & 0,87 & \multirow{2}{*}{0,157} \\
\hline & Papillary carcinoma & 59 & 3,13 & 0,57 & \\
\hline \multirow[t]{2}{*}{ White blood cell count $\left(103 / \mathrm{mm}^{3}\right)$} & Nodular hyperplasia & 180 & 7,61 & 2,00 & \multirow{2}{*}{0,590} \\
\hline & Papillary carcinoma & 95 & 7,47 & 1,92 & \\
\hline \multirow[t]{2}{*}{ Neutrophil/Lenphocyte ratio } & Nodular hyperplasia & 178 & 2,17 & 1,65 & \multirow{2}{*}{0,511} \\
\hline & Papillary carcinoma & 94 & 2,05 & 1,03 & \\
\hline \multirow[t]{2}{*}{ Red blood cell count $\left(103 / \mathrm{mm}^{3}\right)$} & Nodular hyperplasia & 180 & 4,95 & 0,44 & \multirow{2}{*}{0,768} \\
\hline & Papillary carcinoma & 95 & 4,97 & 0,44 & \\
\hline \multirow[t]{2}{*}{ Hemoglobin concentration $(\mathrm{gr} / \mathrm{dl})$} & Nodular hyperplasia & 180 & 13,73 & 1,83 & \multirow{2}{*}{0,327} \\
\hline & Papillary carcinoma & 95 & 13,94 & 1,43 & \\
\hline \multirow[t]{2}{*}{ Red cell distribution width } & Nodular hyperplasia & 180 & 14,36 & 2,53 & \multirow{2}{*}{0,297} \\
\hline & Papillary carcinoma & 95 & 14,07 & 1,54 & \\
\hline \multirow[t]{2}{*}{ Platelet count $\left(103 / \mathrm{mm}^{3}\right)$} & Nodular hyperplasia & 180 & 256,56 & 61,91 & \multirow{2}{*}{0,561} \\
\hline & Papillary carcinoma & 95 & 261,03 & 57,92 & \\
\hline \multirow[t]{2}{*}{ Mean platelet volume (fL) } & Nodular hyperplasia & 180 & 8,63 & 1,08 & \multirow{2}{*}{0,705} \\
\hline & Papillary carcinoma & 94 & 8,57 & 1,33 & \\
\hline \multirow[t]{2}{*}{ Platelet distribution width } & Nodular hyperplasia & 121 & 16,36 & 1,24 & \multirow{2}{*}{0,064} \\
\hline & Papillary carcinoma & 66 & 15,92 & 1,96 & \\
\hline \multirow[t]{2}{*}{ Thyroid weight (gr) } & Nodular hyperplasia & 177 & 85,81 & 82,88 & \multirow{2}{*}{0,000} \\
\hline & Papillary carcinoma & 93 & 43,17 & 33,31 & \\
\hline
\end{tabular}

Table 2. Tumor characteristics of the patients with papillary cancer

\begin{tabular}{lcc}
\hline & $\begin{array}{c}\text { Var } \\
(\mathrm{n})\end{array}$ & $\begin{array}{c}\text { Yok } \\
(\mathrm{n})\end{array}$ \\
\hline The presence of tumor capsule & 59 & 35 \\
\hline Tumor Capsular invasion & 35 & 53 \\
\hline İntrathyroidal spread & 54 & 41 \\
\hline Multicentricity & 37 & 58 \\
\hline Thyroid capsular invasion & 24 & 70 \\
\hline Soft tissue invasion & 17 & 78 \\
\hline Tumor necrosis & 2 & 93 \\
\hline Calcification & 26 & 69 \\
\hline Lymphovascular invasion & 20 & 74 \\
\hline
\end{tabular}

methods that would allow early diagnosis of cancer. Although some markers have been found for some types of cancer, a desirable diagnostic method has yet to be found. This diagnostic method must be available for routine use, cheap and easy to interpret. The question whether or not it is possible to differentiate malignant from benign nodules using the tests readily available at all centers has been the main focus of the present study.

It is important to decide as how to proceed with treatment of a patient, who has been found to have a thyroid nodule, and surgeons and endocrinologists decide on the treatment modality according to the nodule size and morphological appearance suggested by radiological images. 
Table 3. Distribution of histological subvariants of patients with papillary thyroid cancer

\begin{tabular}{lcc}
\hline & $\mathrm{n}$ & $\%$ \\
\hline Diffuse sclerosing & 3 & 3,2 \\
Follicular variant & 27 & 28,4 \\
Classic & 20 & 21,1 \\
Oncocytic & 3 & 3,2 \\
Papillary microcarcinoma & 41 & 43,2 \\
Solid cell Variant & 1 & 1,1 \\
\hline Total & 95 & 100,0 \\
\hline
\end{tabular}

In the literature, benign and malignant thyroid nodules are more commonly reported in females. Jisheng et al. (7) retrospectively evaluated 5559 patients that underwent total thyroidectomy. Of their patients, $87 \%$ were females and $24.3 \%$ of the patients had PTC independent from the gender. Similarly,
$84.7 \%$ of 275 patients in the present study were females and $34.5 \%$ of the patients had PTC. Consistent with the literature, $83.2 \%$ of 95 patients with PTC were females (8).

In a retrospective review of 107 patients that underwent surgery, Koh et al. (9) reported thyroid carcinoma in 8 patients and higher mean age among patients with malignant lesion compared to those with a benign lesion. The present study did not find any difference in mean age between the groups, a finding similar to that reported by Güner et al. (4).

In the study by Miccoli et al. (10) that evaluated 998 patients, thyroid cancer was found to be significantly more prevalent in euthyroid patients compared to patients with thyrotoxicosis. In the present study, TSH levels were significantly lower in patients with nodular hyperplasia compared to patients with PTC $(p<0.003)$, whereas T3 and T4 levels did not show significant difference.

Table 4. Comparative statistics of hematological and hormonal parameters according to the presence of multicentricity in females with papillary cancer

\begin{tabular}{|c|c|c|c|c|c|}
\hline & Multisentrite & $\mathrm{n}$ & Mean & $\mathrm{SD}$ & $\mathrm{p}$ \\
\hline \multirow[t]{2}{*}{ Age } & yes & 50 & 45,44 & 14,51 & \multirow{2}{*}{0,944} \\
\hline & no & 29 & 45,66 & 10,16 & \\
\hline \multirow[t]{2}{*}{ Thyroid stimulating hormone (TSH) } & yes & 50 & 1,37 & 1,21 & \multirow{2}{*}{0,242} \\
\hline & no & 29 & 1,69 & 1,06 & \\
\hline \multirow[t]{2}{*}{ Free thyroxine (fT4) } & yes & 50 & 1,02 & 0,27 & \multirow{2}{*}{0,840} \\
\hline & no & 29 & 1,03 & 0,12 & \\
\hline \multirow[t]{2}{*}{ Free triiodothyronine (fT3) } & yes & 50 & 3,13 & 0,66 & \multirow{2}{*}{0,519} \\
\hline & no & 29 & 3,01 & 0,39 & \\
\hline \multirow[t]{2}{*}{ White blood cell count $\left(103 / \mathrm{mm}^{3}\right)$} & yes & 50 & 7,67 & 2,13 & \multirow{2}{*}{0,195} \\
\hline & no & 29 & 7,08 & 1,55 & \\
\hline \multirow[t]{2}{*}{ Neutrophil/Lenphocyte ratio } & yes & 50 & 2,19 & 1,30 & \multirow{2}{*}{0,199} \\
\hline & no & 29 & 1,86 & 0,57 & \\
\hline \multirow[t]{2}{*}{ Red blood cell count $\left(103 / \mathrm{mm}^{3}\right)$} & yes & 50 & 4,89 & 0,39 & \multirow{2}{*}{0,301} \\
\hline & no & 29 & 4,81 & 0,35 & \\
\hline \multirow[t]{2}{*}{ Hemoglobin concentration $(\mathrm{gr} / \mathrm{dl})$} & yes & 50 & 13,59 & 1,26 & \multirow{2}{*}{0,935} \\
\hline & no & 29 & 13,61 & 1,29 & \\
\hline \multirow[t]{2}{*}{ Red cell distribution width } & yes & 50 & 14,11 & 1,68 & \multirow{2}{*}{0,890} \\
\hline & no & 29 & 14,16 & 1,47 & \\
\hline \multirow{2}{*}{ Platelet count $\left(103 / \mathrm{mm}^{3}\right)$} & yes & 50 & 263,94 & 57,83 & \multirow{2}{*}{0,607} \\
\hline & no & 29 & 270,83 & 55,95 & \\
\hline \multirow[t]{2}{*}{ Mean platelet volume (fL) } & yes & 50 & 8,52 & 1,52 & \multirow{2}{*}{0,779} \\
\hline & no & 29 & 8,61 & 1,06 & \\
\hline \multirow[t]{2}{*}{ Platelet distribution width } & yes & 50 & 15,58 & 2,09 & \multirow{2}{*}{0,047} \\
\hline & no & 29 & 16,56 & 0,82 & \\
\hline \multirow[t]{2}{*}{ Thyroid weight (gr) } & yes & 50 & 39,15 & 30,81 & \multirow{2}{*}{0,982} \\
\hline & no & 29 & 38,98 & 31,09 & \\
\hline
\end{tabular}

Van Tip Derg Cilt:24, Sayı:4, Ekim/2017 
Multicentricity in thyroid cancer can be defined as the presence of thyroid cancer in more than one location in two thyroid lobes. The present tests used in routine practice are not capable of detecting multricentricity particularly in microcarcinomas, which cannot be detected on palpation and show an insidious clinical course (11). The detection of multicentricity in thyroid cancer is important as it may affect treatment methods to be used. The studies in the literature report a multicentricity rate for papillary thyroid carcinoma ranging from $9.5 \%$ to $24.9 \%$, and the rate of multricentricity was $38.9 \%$ in the present study (12, 13).

Pathological subtype is another factor affecting prognosis of papillary thyroid cancer. Girardi et al. (8) evaluated 517 patients with papillary thyroid cancer in their study, in which papillary microcarcinoma, classical type and follicular subtype accounted for $82.9 \%$ of the patients. These three subtypes accounted for $92.7 \%$ of the patients in the present study; however, different from this study, follicular subtype was more prevalent than the classical subtype (7).

The factors stimulating platelet production also cause an increase in platelet distribution width. PDW reflects the increase in the size of the platelets and points to the release of active platelets (6). Increased thrombotic activity can predispose patients to thrombosis and cause problems in some patients. There are studies in the literature reporting a relationship between high PDW and ischemic heart disease. In addition, it can cause vaso-occlusive episodes in patients with sickle-cell anemia $(14,15)$.

Inflammation is a necessary and normal process in the development and advancement of cancer (16). Angiogenesis, inhibition of apoptosis, increased cellular proliferation and decreased resistance against oxidative stress can be regarded as biological effects of inflammation (17). As a result, platelets play an important role in the pathogenesis of cancer through angiogenic, metastatic and proteolytic activities in the background of inflammation (18).

There are a very few studies in the literature regarding the relationship between PDW and malignancies. There is even no study that evaluated the association of PDW with papillary cancer. Karagöz et al. (19) compared patients with lung cancer with healthy individuals and reported high PDW levels in patients with a malignancy. In the same study, MPV was similar in patients with malignancy and healthy individuals. Baldane et al. (20) compared preoperative and postoperative MPV values between patients with PTC and those with nodular goiter and found high MPV values in patients with PTC. In addition, MPV values decreased in the postoperative period in patients with PTC and remained unchanged in patients with papillary thyroid carcinoma. In the present study, PDW and MPV values did not significantly differ between healthy individuals and patients with papillary carcinoma; however, when patients with multicentricity were compared to those without multicentricity, females with multricentricity had higher PDW values ( $\mathrm{p}<0.047)$.

The burning question is whether or not PDW could serve as a diagnostic marker for multicentricity. Further studies are required to say "Yes" to this question. It is recommended to check PDW values in female patients while deciding surgery and cast suspicion of multicentricity if PDW is elevated.

Declaration of interests; The authors declare no conflict of interests

Financial Disclosure; There have been no financial support for this study

\section{References}

1. Chaikhoutdinov I, Mitzner R, Goldenberg D. Incidental Thyroid Nodules: Incidence, Evaluation, and Outcome. Otolaryngol Head Neck Surg 2014; 150(6): 939-942.

2. Lawal O, Agbakwuru A, Olayinka OS, Adelusola K. Thyroid malignancy in endemic nodular goiters; Prevalence, pattern and treatment. Eur J Surg Oncol 2001; 27(2): 157-161.

3. Pellegriti G, Frasca F, Regalbuto C, Squatrito S, Vigneri R. Worldwide increasing incidence of thyroid cancer: update on epidemiology and risk factors. J Cancer Epidemiol 2013; 2013: 965212.

4. Güner A, Kaya MA, Aydın A, Bozkurt S, Kılıç YE, Güler $\mathrm{K}$ ve ark. Multinodüler guatr nedeniyle ameliyat edilen hastalarda insidental tiroid karsinomu. Ulusal Cerrahi Dergisi 2010; 23(3): 87-91.

5. Verdoia M, Barbieri L, Schaffer A, Cassetti E, Di Giovine G, Bellomo G, et al. Platelet distribution width and the risk of periprocedural myocardial infarction in patients undergoing percutaneous coronary intervention. J Thromb Thrombolysis 2014; 37(3): 345-352.

6. Vagdatli E, Gounari E, Lazaridou E, Katsibourlia E, Tsikopoulou F, Labrianou I. Platelet distribution width: a simple, practical and specific marker of activation of coagulation Hipokratia 2010; 14 (1): 2832.

7. Hu J, Zhao N, Kong R, Wang D, Sun B, Wu L. Total thyroidectomy as primary surgical management for thyroid disease: surgical therapy experience from 5559 thyroidectomies in a less-developed region. World J Surg Oncol 2016; 14(1): 20.

8. Girardi FM, Barra MB, Zettler CG. Variants of papillary thyroid carcinoma: Association with 
histopathological prognostic factors. Braz J Otorhinolaryngol 2013; 79(6): 738-744.

9. Koh KBH, Chang KW. Carcinoma in multinodular goitre. Br J Surg 1992; 79(3): 266-267.

10. Miccoli P, Minuto MN, Galleri D, D'Agostino J, Basolo F, Antonangeli L, et al. Incidental thyroid carcinoma in a large series of consecutive patients operated on for benign thyroid disease. ANZ J Surg 2006; 76(3): 123-126.

11. Erol V, Makay Ö, Ertan Y, İçöz G, Akyıldız M, Yilmaz $M$ ve ark. Multicentricity in thyroid papillary microcarcinomas. Ulusal Cerrahi Dergisi 2010; 26(4): 199-202.

12. Vasileiadis I, Karatzas T, Vasileiadis D, Kapetanakis S, Charitoudis G, Karakostas E, et al. Clinical and pathological characteristics ofincidental and nonincidental papillary thyroid microcarcinoma in 339 patients. Head Neck 2014; 36(4): 564-570.

13. Schönberger J, Marienhagen J, Agha A, Rozeboom S, Bachmeier E, Schlitt $\mathrm{H}$, et al. Papillary microcarcinoma and papillary cancer of the thyroid $<$ or $=1 \mathrm{~cm}$ : modified definition of the WHO and the therapeutic dilemma. Nuclearmedizin 2007; 46(4): 115-120.

14. Bekler A, Ozkan MT, Tenekecioglu E, Gazi E, Yener AU, Temiz A ve ark. Increased Platelet Distribution
Width Is Associated With Severity of Coronary Artery Disease in Patients With Acute Coronary Syndrome. Angiology 2015; 66(7): 638-643.

15. Amin MA, Amin AP, Kulkarni HR. Platelet distribution width is increased in vasoocclusive crisis in sickle cell disease. Ann Hematol 2004; 83 (6): 331335.

16. Caruso C, Lio D, Cavallone L, Franceschi C. Aging, longevity, inflammation, and cancer. Ann N Y Acad Sci 2004; 1028: 1-13.

17. Shacter E, Weitzman SA. Chronic inflammation and cancer. Oncology 2002; 16(2): 217-226.

18. Kisucka J, Butterfield CE, Duda DG, Eichenberger SC, Saffaripour S, Ware J, et al. Platelets and platelet adhesion support angiogenesis while preventing excessive hemorrhage. Proc Natl Acad Sci USA 2006; 103(4): 855-860.

19. Karagöz B, Alacacioğlu A, Bilgi O, Demirci $H$, Özgün A, Akyol A ve ark. Platelet count and platelet distribution width increase in lung cancer patients. Anatol J Clin Investig 2009; 3(1): 32-34.

20. Baldane S, Ipekci SH, Sozen M, Kebapcilar L. Mean Platelet Volume Could be a Possible Biomarker for Papillary Thyroid Carcinomas. Asian Pac J Cancer Prev 2015; 16(7): 2671-2674. 